University of Nebraska - Lincoln

DigitalCommons@University of Nebraska - Lincoln

Papers in the Earth and Atmospheric Sciences Earth and Atmospheric Sciences, Department

2009

\title{
Holocene carbon burial by lakes in SW Greenland
}

\author{
N. J. Anderson \\ Loughborough University, Loughborough, UK, N.J.Anderson@lboro.ac.uk
}

W. D'Andrea

Sherilyn C. Fritz

University of Nebraska-Lincoln, sfritz2@unl.edu

Follow this and additional works at: https://digitalcommons.unl.edu/geosciencefacpub

Part of the Earth Sciences Commons

Anderson, N. J.; D'Andrea, W.; and Fritz, Sherilyn C., "Holocene carbon burial by lakes in SW Greenland" (2009). Papers in the Earth and Atmospheric Sciences. 108.

https://digitalcommons.unl.edu/geosciencefacpub/108

This Article is brought to you for free and open access by the Earth and Atmospheric Sciences, Department of at DigitalCommons@University of Nebraska - Lincoln. It has been accepted for inclusion in Papers in the Earth and Atmospheric Sciences by an authorized administrator of DigitalCommons@University of Nebraska - Lincoln. 
Published in Global Change Biology 15:11 (2009), pp. 2590-2598 doi: 10.1111/j.1365-2486.2009.01942.x

Copyright $\odot 2009$ Blackwell Publishing Ltd. Used by permission.

Submitted January 11, 2009; accepted March 16, 2009; published online April 9, 2009.

\title{
Holocene carbon burial by lakes in SW Greenland
}

\author{
N. J. Anderson, ${ }^{1}$ W. D' Andrea, ${ }^{2}$ and S. C. Fritz ${ }^{2}$ \\ ${ }^{1}$ Department of Geography, Loughborough University, Loughborough, LE11 3TU, UK \\ ${ }^{2}$ Department of Geosciences and School of Biological Sciences, \\ University of Nebraska-Lincoln, 302 Bessey Hall, Lincoln, NE 68588-0340, USA \\ Corresponding author - N. John Anderson, e-mail N.J.Anderson@lboro.ac.uk \\ Present address for W. D'Andrea - Department of Geosciences, \\ University of Massachusetts-Amherst, Amherst, MA 01003-9297, USA
}

\begin{abstract}
The role of the Arctic in future global change processes is predicted to be important because of the large carbon (C) stocks contained in frozen soils and peatlands. Lakes are an important component of arctic landscapes although their role in storing $C$ is not well prescribed. The area around Kangerlussuaq, SW Greenland $\left(66-68^{\circ} \mathrm{N}, 49-54^{\circ} \mathrm{W}\right)$ has extremely high lake density, with 20000 lakes that cover about $14 \%$ of the land area. $\mathrm{C}$ accumulation rates and standing stock $\left(\mathrm{kg} \mathrm{C} \mathrm{m}^{-2}\right)$, representing late- to mid-Holocene $\mathrm{C}$ burial, were calculated from AMS ${ }^{14} \mathrm{C}$-dated sediment cores from 11 lakes. Lake ages range from $\sim 10000 \mathrm{cal} \mathrm{yr} \mathrm{bp} \mathrm{to} \sim 5400 \mathrm{cal} \mathrm{yr} \mathrm{bp}$, and reflect the withdrawal of the ice sheet from west to east. Total standing stock of $\mathrm{C}$ accumulated in the studied lakes for the last $\sim 8000$ years ranged from 28 to $71 \mathrm{~kg}^{\mathrm{C}} \mathrm{m}^{-2}$, (mean: $\sim 42 \mathrm{~kg} \mathrm{C} \mathrm{m}^{-2}$ ). These standing stock determinations yield organic $\mathrm{C}$ accumulation rates of $3.5-11.5 \mathrm{~g} \mathrm{C} \mathrm{m}^{-2} \mathrm{yr}^{-1}$ (mean: $\sim 6 \mathrm{~g} \mathrm{C} \mathrm{m}^{-2} \mathrm{yr}^{-1}$ ) for the last 4500 years. Mean $\mathrm{C}$ accumulation rates are not different for the periods 8-4.5 and 4.5$0 \mathrm{ka}$, despite cooling trends associated with the neoglacial period after $4.5 \mathrm{ka}$. We used the mean $\mathrm{C}$ standing stock to estimate the total C pool in small lakes ( $<100 \mathrm{ha}$ ) of the Kangerlussuaq region to be $\sim 4.9 \times 10^{13} \mathrm{~g}$ C. This C stock is about half of that estimated for the soil pool in this region (but in $5 \%$ of the land area) and indicates the importance of incorporating lakes into models of regional C balance at high latitudes.
\end{abstract}

Keywords: arctic, carbon, mineralization, soils, tundra

\section{Introduction}

The potential relevance of lakes to the global carbon (C) budget has received attention recently with the realization that lakes form an important component of the terrestrial C cycle (Algesten et al., 2004; Cole et al., 2007; Downing et al., 2008). Estimates of the rate of global C burial by lakes suggest burial rates ranging from 0.03 to $0.07 \mathrm{Pg} \mathrm{C} \mathrm{yr}^{-1}$ (Cole et al., 2007). A determination of the total $\mathrm{C}$ stored in lake sediments within a given region requires estimates of the areal coverage of lakes and the mean $\mathrm{C}$ standing stock $\left(\mathrm{kg} \mathrm{C} \mathrm{m}^{-2}\right)$ for the basins (Kortelainen et al., 2004). Most estimates of $C$ burial by lakes have relied on values for $\mathrm{C}$ accumulation rate derived from a single or very few sites within a geographic area. For example, Dean \& Gorham (1998) estimated global $\mathrm{C}$ burial by small lakes to be on the order of $70 \mathrm{~g} \mathrm{C} \mathrm{m}^{-2} \mathrm{yr}^{-1}$, based on $\mathrm{C}$ accumulation rates in three lakes. Stallard (1998) suggested a lower rate of $4.5 \mathrm{~g} \mathrm{C} \mathrm{m}^{-2} \mathrm{yr}^{-1}$. The most comprehensive study is that of Kortelainen et al. (2004), who took advantage of the Nordic Lake Survey database and used C standing stock determinations from 122 lakes (mean burden $19 \mathrm{~kg} \mathrm{~m}^{-2}$ ) to estimate that Holocene $\mathrm{C}$ burial by all Finnish lakes is $1.8 \mathrm{~g} \mathrm{C} \mathrm{m}^{-2} \mathrm{yr}^{-1}$. The applicability of these $\mathrm{C}$ burial estimates to arctic lakes is not known, but considering the large variability among the estimates to date and the generally lower productivity of arctic lakes relative to boreal and temperate lakes (due to shorter growing season and lower nutrient availability) (Lizotte, 2008), they may be inappropriate. Thus, better regional/local estimates of $C$ burial are needed to increase our understanding of the role of lakes in regional C budgets (Kling et al., 1991; Cole et al., 2007).

Arctic soils represent a considerable component of the global terrestrial C storage (Hobbie et al., 2000), with a substantial component of the $C$ pool locked-up by permafrost and essentially removed from the contemporary $\mathrm{C}$ cycle. The threat of increased mineralization of this $C$ pool due to rising temperatures is consid- 
ered to be an important aspect of future change at high latitudes (Oechel \& Billings, 1992; Mack et al., 2004). The $\mathrm{C}$ content of arctic soils, however, varies with dominant vegetation types. The highest soil $C$ content is associated with wet sedge tundra whereas dwarf shrub tundra soils contain considerably less (Oechel \& Billings, 1992). Much of the arctic is quite dry (and predicted to get drier), which also provides constraints on primary production and terrestrial C accumulation (Kane et al., 1992). In this context, in lake-rich arctic landscapes, the aquatic component of $\mathrm{C}$ burial may be a substantial long-term sink. Glaciated landscapes often have a very high density of lakes, and Oechel \& Billings (1992) have estimated that $C$ in arctic soils has a turnover time of $\sim 500$ years, which contrasts to the effective long-term burial of $\mathrm{C}$ by lakes spanning thousands of years (Cole et al., 2007). Some of the soil-C is released from terrestrial systems as dissolved organic carbon (DOC) and subsequently transported to streams and lakes where it is transformed and processed by microbial activity (Kling et al., 1991; Sobek et al., 2003). A portion of this C-pool is released via respiration, but some may be retained and stored in sediments. Moreover, productivity of arctic lakes is predicted to increase as a function of a longer growing season, and potentially via nutrient stimulation, so future C storage may be higher.

Here we report mean Holocene $C$ standing stock and $\mathrm{C}$ accumulation rates for 11 lakes in SW Greenland.
These measured values are then used to estimate the $C$ pool in small lakes ( $<100 \mathrm{ha})$ in the Kangerlussuaq region. These calculations represent the first estimates of C burial by aquatic systems in a dry, dwarf shrub tundra-dominated landscape and provide some initial constraints on the magnitude of aquatic $\mathrm{C}$ burial in arctic landscapes.

\section{Methods}

\section{Study area}

Kangerlussuaq (Søndre Strømfjord in Danish; $67^{\circ} \mathrm{N}$, $55^{\circ} \mathrm{W}$; Figure 1), a long glacial valley draining the Greenland ice sheet, is a glacially-scoured landscape with a high density lakes of varied size. The region is the largest ice-free area in West Greenland, with a maximum width of $\sim 170 \mathrm{~km}$. The geology is predominantly granodioritic gneiss. The climate is low arctic continental, with mean annual temperature of $-6.0^{\circ} \mathrm{C}$ and low annual precipitation $\left(\sim 150 \mathrm{~mm} \mathrm{yr}^{-1}\right)$ near the inland head of the fjord. At the coast, the annual temperature range is reduced, and precipitation can exceed $500 \mathrm{~mm} \mathrm{yr}^{-1}$. The inland area has high rates of evaporation in the summer despite an August precipitation maximum (Hasholt \& Søgaard, 1978). The resultant negative hydrological balance produces a number of

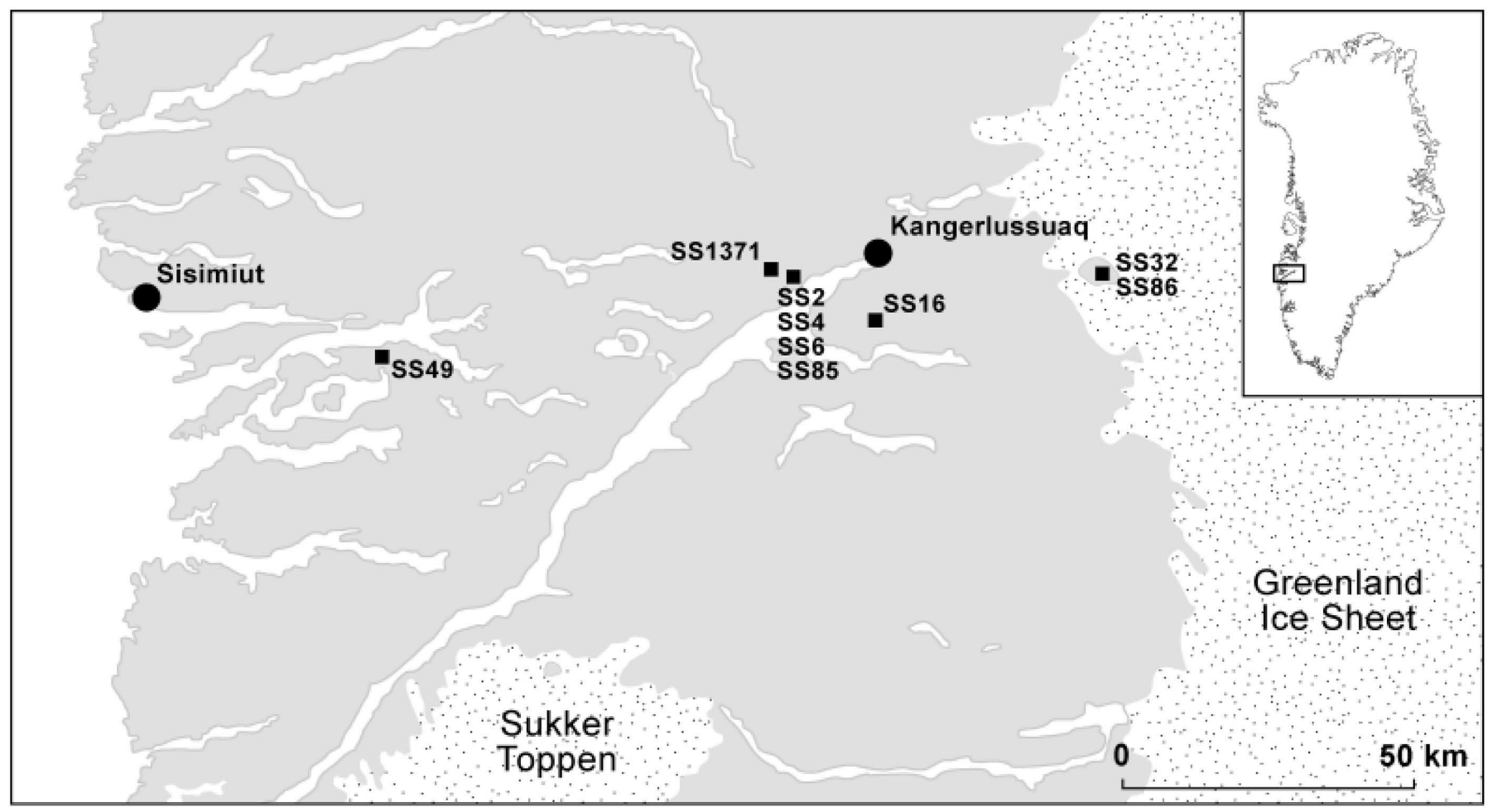

Figure 1. Location of the study sites along Søndre Strømfjord. Stippled area indicates the present-day extent of the Greenland ice sheet and Sukkertoppen ice cap. 
Table 1. Summary physical and chemical characteristics of the study sites

\begin{tabular}{|c|c|c|c|c|c|c|c|c|}
\hline Lake & $\begin{array}{l}\text { Latitude } \\
\left({ }^{\circ} \mathrm{N}\right)\end{array}$ & $\begin{array}{l}\text { Longitude } \\
\left({ }^{\circ} \mathrm{W}\right)\end{array}$ & $\begin{array}{l}\text { Altitude } \\
(\mathrm{m})\end{array}$ & $\begin{array}{l}\text { Area } \\
\text { (ha) }\end{array}$ & $\begin{array}{r}\text { Maximum } \\
\text { depth }(\mathrm{m})\end{array}$ & $\begin{array}{c}\text { Anoxic } \\
\text { hypolimnion }\end{array}$ & $\begin{array}{l}\text { Conductivity } \\
\left(\mu \mathrm{S} \mathrm{cm}^{-1}\right)\end{array}$ & $\begin{array}{c}\text { DOC } \\
\left(\mathrm{mg} \mathrm{L}^{-1}\right)\end{array}$ \\
\hline SS2 & 66.99 & 50.97 & 185 & 36.8 & 11.2 & No & 320 & 40.6 \\
\hline SS6 & 66.99 & 51.11 & 175 & 21.5 & 12.8 & Yes & 3244 & 106.1 \\
\hline SS16 & 66.91 & 50.46 & 477 & 3.3 & 12.2 & Yes & 107 & 10.2 \\
\hline SS32 & 66.96 & 49.80 & 470 & 16.3 & 21 & No & 51 & 7.6 \\
\hline SS85 & 66.98 & 51.08 & 178 & 24.6 & 12 & Occasional & 616 & 58.9 \\
\hline SS86 & 66.96 & 49.81 & 470 & 5 & 13 & Yes & 334 & 30.7 \\
\hline SS1371 & 67.06 & 51.13 & 150 & 21.7 & 22 & Yes & 3420 & 83.1 \\
\hline
\end{tabular}

DOC $=$ dissolved organic carbon.

athalassic oligosaline lakes and the absence of extensive vegetation and organic soil development on SW facing slopes, where moisture stress is high. Where moisture supply is adequate, the dominant vegetation is dwarf shrub tundra, with Betula nana, Salix spp., Rhododendron and Ledum sp. as important components. Towards the coast, Ericaceae are relatively more important. Soils have mean $C$ content of $8 \pm 7 \%$ and have maximum depths of $<50 \mathrm{~cm}$, except in low relief and wetter areas (e.g. valley floors and around the outflows to lakes). Permafrost is extensive and extends below a depth of $\sim 30 \mathrm{~cm}$ (R. Bindler et al., unpublished results).

The Kangerlussuaq region, defined in this study as the area between 66 and $68^{\circ} \mathrm{N}$ (Figure 1) and from 49 to $54^{\circ} \mathrm{W}$ (i.e. the ice sheet margin to the coast) contains 19813 lakes covering a total area of 318506 ha. Lakes range from small ponds of $\sim 1$ ha to large fjord systems with areas $>1000$ ha, although the majority of lakes $(80 \%)$ are smaller than $10 \mathrm{ha}$, and these represent $\sim 10 \%$ of the total lake area. Lake water chemistry is $\mathrm{Na}-\mathrm{Mg} \mathrm{CO}_{3}$ - dominated, with variable ionic concentration, ranging from oligosaline (conductivities of $2500-4000 \mu \mathrm{S} \mathrm{cm}^{-1}$ ), to dilute (conductivity $<25 \mu \mathrm{S} \mathrm{cm}{ }^{-1}$ ) (Anderson et al., 2001). Lake DOC concentrations range from $<10 \mathrm{mg} \mathrm{L}^{-1}$ in the lakes at the coast and near the ice margin to $\sim 100 \mathrm{mg} \mathrm{C} \mathrm{L}^{-1}$ in the meromictic, oligosaline lakes (Anderson \& Stedmon, 2007) (Table 1). There are no estimates of lake productivity, but nutrient concentrations are low in most lakes, with highest values in the oligosaline lakes.

\section{Analytical methods}

The cores used here to calculate organic carbon accumulation rates (OC AR) were taken originally as part of other projects, primarily paleoclimate studies, but also for reconstruction of past lake biological structure and ecosystem functioning, and long-term $\mathrm{Hg}$ deposition (McGowan et al., 2003; Anderson \& Leng, 2004;
Lindeberg et al., 2006; Anderson et al., 2008). Cores were taken from the deepest part of each lake basin using a Russian peat corer, while surface sediments were obtained using either a Hon-Kajak corer or freeze core (see McGowan et al., 2003 for details). Dating control is provided by ${ }^{14} \mathrm{C}$ AMS dates on either bulk organic content or terrestrial macrofossils. Cores were sectioned at 0.5 or $1-\mathrm{cm}$ intervals. Organic matter content was determined using loss-on-ignition (LOI) at $550{ }^{\circ} \mathrm{C}$ for $2 \mathrm{~h}$ or $\mathrm{C}$ content was measured by an elemental analyzer. Organic content determined by LOI was converted to C content using a correction factor of 0.469 (Dean, 1974). Where percent dry weight was not measured directly, it was estimated using relationships determined from other sites. Inorganic C burial is ignored in our calculations, as only two oligosaline lakes have measurable inorganic C. Data from two lakes (NAUJG and SFL) studied by Willemse \& Tornqvist (1999) also are included here (data are available from the NOAA data repository).

Sediment bulk density was calculated using standard relationships and corrected for $C$ content to derive total $\mathrm{C}$ standing stock, as $\mathrm{kg} \mathrm{C} \mathrm{m}^{-2}$. Radiocarbon chronologies were used to convert $\mathrm{C}$ content $\left(\mathrm{g} \mathrm{C} \mathrm{cm}^{-3}\right)$ to $\mathrm{C}$ AR $\left(\mathrm{g} \mathrm{C} \mathrm{m}^{-2} \mathrm{yr}^{-1}\right)$. C standing stock $\left(\mathrm{kg} \mathrm{C} \mathrm{m}^{-2}\right)$ was estimated for two time periods, the early Holocene from $\sim 8000$ to 4500 calibrated years before present (cal yr bp), when temperatures were warmer than at present (DahlJensen et al., 1998), and for the neoglacial, 4500 cal yr bp to present, an interval of regional cooling (Kaufman et al., 2004).

Sediment focusing was not addressed systematically in this study for logistic reasons. Errors associated with depositional differences within a single lake basin (SS16) fall within the range of measured $\mathrm{C}$ accumulation among the 11 basins (Figure 2) but sediment accumulation was not uniform in space or time (see Table 2). It is a major problem for regional upscaling and the extent to which it will contribute to the error associated with estimating regional C stock is unknown (see "Discussion"). 


\section{Regional C-burial estimates}

The total number of lakes in the study area was estimated using ArcInfo, and lake outlines (shape files) were derived from the KMS 1 : 250000 map coverage of the area (sheets: $66 \mathrm{V1}, \mathrm{V} 2$ and $67 \mathrm{~V} 1, \mathrm{~V} 2$ ). Lakes with area $<1$ ha were discarded due to possible errors in determining the areas of small water bodies at this scale. The total lake area was combined with the calculated C stock defined above to give an estimate of the regional lake $\mathrm{C}$ pool.

The part of the study area presently vegetated is $12,280 \mathrm{~km}^{2}$, about $53 \%$ of the nonlake land area $\left(23,169 \mathrm{~km}^{2}\right)$ and was estimated using an unsupervised NDVI algorithm classification of a Landsat image. To estimate terrestrial $\mathrm{C}$ pools, a mean $\mathrm{C}$ content for dwarf shrub tundra soils $\left(6.7 \mathrm{~kg} \mathrm{C} \mathrm{m}^{-2}\right)$ was taken from published estimates (Elberling et al., 2004; Jensen et al., 2006) and assumes a mean soil depth of $60 \mathrm{~cm}$ (see "Discussion"), which is probably an overly generous estimate given the thin soils in much of the study area (Böcher, 1949).

\section{Results}

Lake ages range from $\sim 10000$ cal yr bp near the coast (SS49) to $\sim 5500$ cal yr bp for the two lakes located on a nunatak within the Greenland ice sheet near its western margin $\left(66^{\circ} \mathrm{N} 49^{\circ} \mathrm{W}\right)$. The ages largely reflect the known deglaciation history for this area (van Tatentove et al., 1996), although there is some local variability (compare SS2 and SS85, located <5 km apart) (Figure 1; Table 2).
The total C-standing stock contained in the entire sediment column of individual lakes ranged from 28 to $71 \mathrm{~kg} \mathrm{~m}^{-2}$, excluding the two nunatak sites, which were substantially lower $\left(\sim 9 \mathrm{~kg} \mathrm{C} \mathrm{m}^{-2}\right)$. Calculated standing stock for the hypsithermal period (8000-4500 cal yr bp) ranged from $10.8 \mathrm{~kg} \mathrm{C} \mathrm{m}^{-2}$ at lake SS2 to $30.4 \mathrm{~kg} \mathrm{C} \mathrm{m}^{-2}$ at SS16, both freshwater systems (Table 2). The neoglacial period (last 4500 years) values ranged from $15.6 \mathrm{~kg} \mathrm{C} \mathrm{m}^{-2}$ at SS2 to $52 \mathrm{~kg} \mathrm{C} \mathrm{m}^{-2}$ at SS1371, an oligsaline lake with an anoxic hypolimnion. The total $\mathrm{C}$ standing stock for lakes $<100$ ha in the Søndre Strømfjord area is $\sim 4.9 \times 10^{13} \mathrm{~g} \mathrm{C}$ (Table 3). Applying the estimated mean

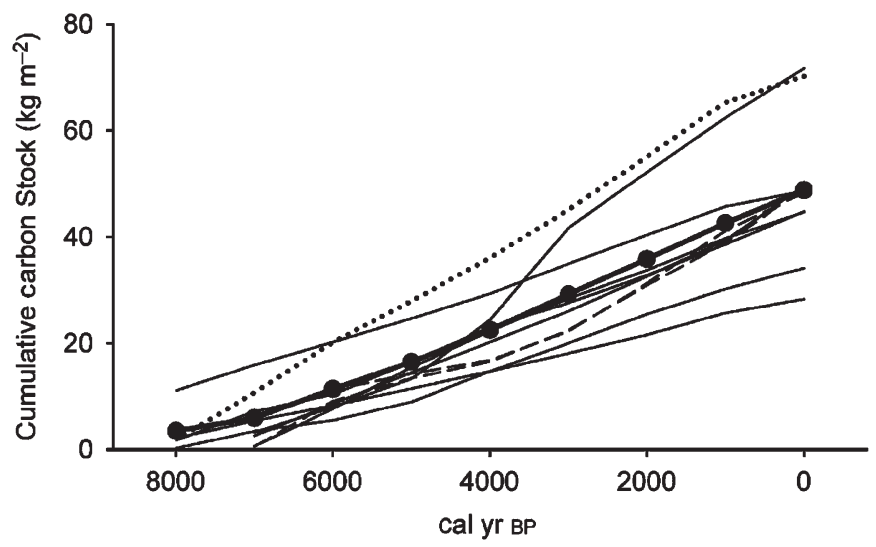

Figure 2. Carbon standing stock from nine lakes (nunatak lakes: SS32 and SS86 are not shown) in southwestern Greenland. Thick line represents mean values of all nine lakes. The dotted and dashed lines are the maximum and minimum standing stocks (respectively) for a single lake (SS16), derived from cores taken from different water depths.

Table 2. Carbon inventories for whole cores (from core base) and selected time periods the hypsithermal (prior to 4500 cal yr bp) and the neoglacial (post $4500 \mathrm{cal}$ yr bp)

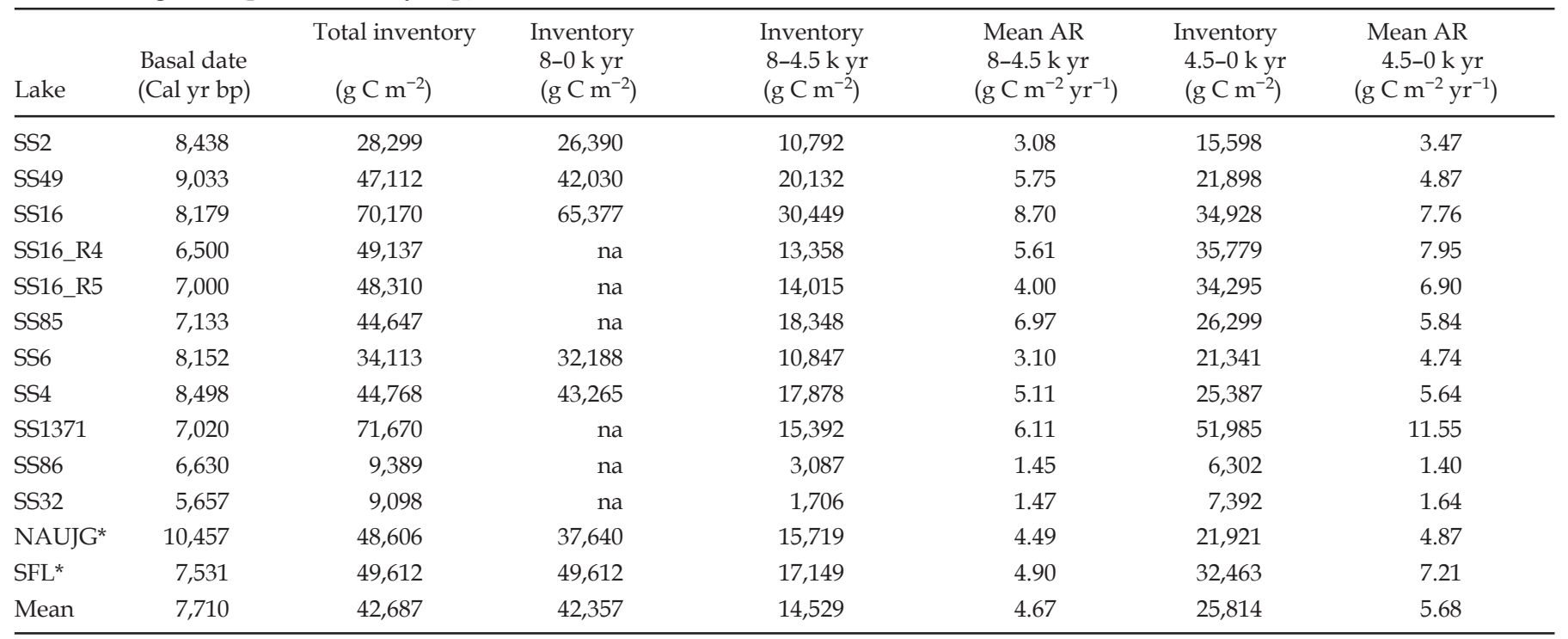

* Data for NAJG and SFl are derived from Willemse \& Tornquist (1999)

$\mathrm{AR}=$ accumulation rate; na $=$ not applicable. 
Table 3. Total number of lakes in the study area (Figure 1) for given lake area ranges, cumulative lake areas and estimated regional annual $\mathrm{C}$ burden assuming a mean $\mathrm{C}$ burial of $42 \mathrm{~kg} \mathrm{C} \mathrm{m}^{-2}$ lake area

\begin{tabular}{lrccc}
\hline $\begin{array}{l}\text { Lake area } \\
\text { (ha) }\end{array}$ & $\begin{array}{r}\text { Number } \\
\text { of lakes }\end{array}$ & $\begin{array}{c}\text { Lake area (ha) } \\
\text { for size category }\end{array}$ & $\begin{array}{c}\text { Total C burden } \\
\left(\mathrm{gC} \times 10^{13} \mathrm{~m}^{-2}\right) \text { for } \\
\text { lake size category }\end{array}$ & $\begin{array}{c}\text { Cumulative total } \\
\text { regional C burial by } \\
\text { lakes }\left(\mathrm{gC} \times 10^{13} \mathrm{~m}^{-2}\right)\end{array}$ \\
\hline$<10$ & 16,379 & 36,437 & 1.53 & 1.53 \\
$10-50$ & 2,565 & 54,158 & 2.275 & 3.81 \\
$50-100$ & 375 & 25,979 & 1.091 & 4.896 \\
$100-1000$ & 470 & 118,931 & $2.497^{*}$ & 7.39 \\
$>1000$ & 24 & 83,001 & $0.830^{\dagger}$ & 8.223 \\
Total & 19,813 & 318,506 & & 8.223 \\
Vegetated area (ha) & & $1,227,957$ & & 8.23 \\
\hline
\end{tabular}

$\mathrm{C}$ burial on land is also given and assumes a mean $\mathrm{C}$ soil content of $6.7 \mathrm{kgm}^{-2}$ (see Jensen et al., 2006).

* A burden of $20 \mathrm{kgCm}^{-2}$ was used to estimate total $\mathrm{C}$ burden for this lake size.

$\dagger_{\mathrm{A}}$ burden of $10 \mathrm{Ckg}^{-2}$ was used to estimate total $\mathrm{C}$ burden for this lake size (see main text).

stock of $42 \mathrm{~kg} \mathrm{~m}^{-2}$ to all lakes in the Søndre Strømfjord region provides a total lake sediment $C$ standing stock of $13.4 \times 10^{13} \mathrm{~g} \mathrm{C}$. This burden $\left(42 \mathrm{~kg} \mathrm{C} \mathrm{m}^{-2}\right)$ is, however, probably inappropriate for large lakes (it is well known that C-burial is reduced in large lakes) and so reduced burdens $\left(20\right.$ and $10 \mathrm{~kg} \mathrm{C} \mathrm{m}^{-2}$ ) were used for lakes $>100$ and $>1000$ ha respectively. Applying these reduced burdens to the larger lakes gives an estimated regional $\mathrm{C}$ stock for all lakes of $8.22 \times 10^{13} \mathrm{~g} \mathrm{C}$ (Table 3). Applying the maximum and minimum estimates of standing stock (excluding the nunatak lakes) to those lakes $<100$ ha, the range of regional Holocene $\mathrm{C}$ burial was estimated as 3.26-7.8 × $10^{13} \mathrm{~g} \mathrm{C}$ (Table 2; see "Discussion"). The estimated terrestrial soil $\mathrm{C}$ content for the region is $8.23 \times$ $10^{13} \mathrm{~g} \mathrm{C}$ (Table 3).

The total standing stock within an individual lake equates to an average OC AR for the hypsithermal ( 3500 years) of $5 \mathrm{~g} \mathrm{C} \mathrm{m}^{-2} \mathrm{yr}^{-1}$ (range: 3$8.7 \mathrm{~g} \mathrm{C} \mathrm{m}^{-2} \mathrm{yr}^{-1}$ ) (Table 2). Mean $\mathrm{C}$ accumulation rates for the neoglacial were 3.5-11.6 $\mathrm{g} \mathrm{C} \mathrm{m}^{-2} \mathrm{yr}^{-1}$ for all sites except the nunatak lakes, which were substantially lower $\left(\sim 1.5 \mathrm{~g} \mathrm{C} \mathrm{m}^{-2} \mathrm{yr}^{-1}\right)$.

\section{Discussion}

The mean $\mathrm{C}$ standing stock estimated for the SW Greenland lakes is $42 \mathrm{~kg} \mathrm{C} \mathrm{m}^{-2}$ (range $\sim 28-71 \mathrm{~kg} \mathrm{C} \mathrm{m}^{-2}$; Table 2) compared with $19 \mathrm{~kg} \mathrm{C} \mathrm{m}^{-2}$ for all Finnish lakes (Kortelainen et al., 2004). However, the average standing stock for small Finnish lakes $\left(<1 \mathrm{~km}^{2}\right)$ is similar to that observed here. The total lake sediment C pool for the Kangerlussuaq region (Figure 1) (which is $\sim 6.8 \%$ of the area of Finland) was estimated to be $\sim 0.082 \mathrm{Pg} \mathrm{C}$. Finnish lakes contain $\sim 0.60 \mathrm{Pg} \mathrm{C}$ in a lake area of $34000 \mathrm{~km}^{2}$ (Kortelainen et al., 2004). In the
Finnish study, small lakes (defined as $<1000 \mathrm{ha}$ ) buried two-thirds of the $C$ store of all Finnish lakes although they represent only one-third of the lake area. Similarly, small lakes (<1000 ha) dominate the total lake area in SW Greenland (Table 3). The C burden calculated in this study $\left(42 \mathrm{~kg} \mathrm{C} \mathrm{m}^{-2}\right)$ is probably only applicable to lakes $<100$ ha (the area of the largest lake studied is 73 ha; Table 1), and this value is unlikely to be appropriate for extrapolation to larger lakes (>100 ha) or to the very large fjord systems, which commonly exceed 1000 ha. C preservation and burial are inversely related to lake depth, and the large deep lakes in the Kangerlussuaq area are probably accumulating only small amounts of organic sediment, because of considerable mineralization of the $C$ fixed in the epilimnion within the deep, oxygenated water columns (Kalff, 2002; Cotner et al., 2004).

The degree of error in upscaling the mean $C$ stock derived from 10 lakes to 19000 (Table 3) is considerable; Kortelainen et al. (2004) measured C burial in 122 lakes and extrapolated this to 56000 lakes in Finland. The approach taken in Finland was not possible logistically in SW Greenland. Excluding the problems of estimating $C$ in the large lakes (>1000 ha), the similarity of the standing stock estimates at the mainland lakes (range $28-71 \mathrm{~kg} \mathrm{C} \mathrm{m}^{-2}$ ), suggests use of a mean value of $42 \mathrm{~kg} \mathrm{C} \mathrm{m}^{-2}$ is acceptable.

The average $\mathrm{C}$ burial by SW Greenland lakes over the last 8000 years is $\sim 5 \mathrm{~g} \mathrm{C} \mathrm{m}^{-2} \mathrm{yr}^{-1}$, which is low when compared to eutrophic impoundments (Downing et al., 2008) but higher than that reported by Kortelainen et al. (2004). Clearly, the OC AR used by Dean \& Gorham (1998) are inappropriate for arctic lakes. The higher rate derived from the Minnesota lakes likely reflect the higher productivity in this temperate midcontinental location, as well as more pronounced sed- 
iment focusing. The value proposed by Stallard (1998) $\left(4.5 \mathrm{~g} \mathrm{C} \mathrm{m}^{-2} \mathrm{yr}^{-1}\right)$ is close to that estimated here (Table 2 ). For comparison, the average $C$ accumulation rate for tundra is $1.2 \mathrm{~g} \mathrm{C} \mathrm{m}^{-2} \mathrm{yr}^{-1}$ (Schlesinger, 1997). However, the variability of soil $\mathrm{C}$ accumulation rate varies considerably with vegetation type (Oechel \& Billings, 1992). For example, the average $C$ accumulation rate for wet coastal tundra soils is estimated to be $27 \mathrm{~g} \mathrm{C} \mathrm{m}^{-2} \mathrm{yr}^{-1}$ (Oechel \& Billings, 1992), considerably higher than the soil $\mathrm{C}$ accumulation rates on Disko Island (3.1$6.7 \mathrm{~g} \mathrm{C} \mathrm{m}^{-2} \mathrm{yr}^{-1}$ ) reported by Jensen et al. (2006) and used here (Table 3 ).

The $\mathrm{C}$ stock (and mean accumulation rates) at the two nunatak lakes are substantially lower than the majority of other lakes in this study (Table 2). The lower cumulative Holocene totals reflect their age; they are 2000-3000 years younger than lakes further west. However, the burdens for the neoglacial are also lower (Table 2). The location is substantially cooler than the inland sites (their average epilimnetic lakewater temperature is $\sim 8{ }^{\circ} \mathrm{C}$ compared with $14{ }^{\circ} \mathrm{C}$ for the mainland sites (see Kettle et al., 2004) and consistently windier due to katabatic winds flowing off the ice sheet. However, the two lakes are also different limnologically from one another, providing an interesting perspective of the role of limnology on C preservation. SS32 has an outflow, is larger and is isothermal (Table 1). SS86 has no outflow, is more chemically concentrated and is strongly stratified. Despite these limnological differences, the $\mathrm{C}$ standing stock is very similar (Table 2). Thus, the lower $C$ burdens may reflect lower initial productivity due to lower average water temperatures. Among all lakes, however, long-term climate change does not appear to have a pronounced effect on $C$ burial based on a comparison of hypsithermal and neoglacial values (Table 2). The Greenland ice core record (Dahl-Jensen et al., 1998) suggests a $2{ }^{\circ} \mathrm{C}$ difference between these two intervals. Oechel et al. (1997) reported a near fivefold reduction in $\mathrm{C}$ accumulation rates (6.7-1.2 $\left.\mathrm{g} \mathrm{C} \mathrm{m}^{-2} \mathrm{yr}^{-1}\right)$ in a wet-sedge tundra soil at Prudhoe Bay, Alaska after 5000 cal yr bp. On Disko Island (W. Greenland), Jensen et al. (2006) also found that $\mathrm{C}$ accumulation in soils was higher in the early Holocene and declined from 10000 to $7000 \mathrm{cal} \mathrm{yr} \mathrm{bp}$ (from 6.7 to $3.1 \mathrm{~g} \mathrm{C} \mathrm{m}^{-2} \mathrm{yr}^{-1}$ ).

\section{Errors in estimating $C$ standing stock}

C content of lake sediments is a reflection of a number of factors: initial in-lake primary productivity, external inputs, dilution by a minerogenic inputs, postdepositional mineralization, within-basin sedimentation processes, and wash-out (loss). Moreover, sediment (and organic matter) accumulation in lakes is spatially heterogeneous (Rippey et al., 2008). The extended periods of ice cover and the rapid on set of thermal stratification immediately after ice out in arctic lakes suggests that resuspension may not be as prevalent as in temperate lakes. The effects of ice scouring in the littoral zone are, however, not known.

Sediment focusing was not addressed in a systematic way in this study, largely for logistic reasons and is rarely undertaken in studies of sediment accumulation over Holocene timescales. At SS16, multiple cores were taken, however, and analysis of three full core profiles from this basin (Table 2; Figure 2) suggests that sediment focusing of material from shallow into deep water is responsible for the high $\mathrm{C}$ standing stock before $4500 \mathrm{cal}$ yr bp, estimated based on a central lake core. After this date, the degree of sediment focusing diminished as indicated by the more similar standing stock estimates for the neoglacial period $\left(\sim 35 \mathrm{~kg} \mathrm{C} \mathrm{m}^{-2}\right.$ for all three cores) (Table 2). The main basin at SS16 is presently $\sim 13 \mathrm{~m}$ deep, but is relatively small and likely trapped sediment more effectively in the early Holocene when it was ca. $2 \mathrm{~m}$ deeper. A multicore study of recent (last 100-years) sediment accumulation at SS16 (based on ${ }^{210} \mathrm{~Pb}$-dated short cores) indicated minimal sediment focusing over the last 100 years (N. J. Anderson, unpublished results). Despite the observed temporal variability, the differences in $\mathrm{C}$ accumulation calculated from the three SS16 cores are comparable to the range observed at the other 11 lakes in this study (Figure 2). Sediment focusing will, however, contribute to the error in the regional $\mathrm{C}$ burial estimates.

Postdeposition mineralization is presumably quite slow in arctic lake sediments because of the low temperatures and anoxic porewaters (Sand-Jensen et al., 1999). Five of the lakes where $C$ stock was calculated have anoxic hypolimnia today (Table 1), which presumably reduces mineralization during settling and at the sediment-water interface. Although the role of anoxia in organic $C$ preservation is assumed to be important, this need not be the case (Meyers, 1994). The lakes used in this study include a range of lake types, from meromictic systems (permanently stratified with anoxic hypolimnia, e.g. SS4, SS1371), through shallow oxygenated holomictic lakes (SS49) to dimictic lakes that today are anoxic both in the summer and winter (e.g. SS16). The extent to which these stratification patterns have changed over time is not known. At one site (SS4), however, the pigment record of okenone (associated with purple sulphur bacteria, which are anaerobes) is not continuous throughout the Holocene, which suggests that stratification history has been variable (McGowan et al., 2008). The role of anoxia is difficult to assess and may not be very significant given the similarity of $\mathrm{C}$ stock across all lakes (Table 2). For example, at SS4, the chemocline today is still quite deep 
(15 m), which allows $\mathrm{C}$ mineralization in the water column, whereas at SS1371, anoxia starts at $5 \mathrm{~m}$, which reduces the extent of mineralization during particle settling. Similarly, the $\mathrm{C}$ burdens are quite similar for lakes with different developmental histories, including lakes that have undergone evaporative concentration (due to changing local precipitation balances), as well as lakes that have remained fresh and become more oligotrophic through time (Anderson et al., 2008; McGowan et al., 2008)).

\section{C sources}

The amount of allochthonous $\mathrm{C}$ input to Greenland lakes is not known, but several factors suggest that the $\mathrm{C}$ being buried is mainly generated within the lake. Although the Søndre Strømfjord lakes have high DOC concentration, DOC is assumed to be primarily autochthonous and concentrated via evaporative concentration (Anderson \& Stedmon, 2007). A predominantly autochthonous source (i.e. algae) for organic $\mathrm{C}$ in the lakes is suggested by the consistently low $\mathrm{C} / \mathrm{N}$ ratio $(\sim 10 ; \mathrm{N}$. J. Anderson, unpublished results) (Meyers, 1994) and by the limited hydrologic linkage between the regional lakes and their catchments (Anderson \& Stedmon, 2007). The hydrological balance of the lakes along Søndre Strømfjord is largely dependent on winter snow fall and the resultant late spring surface runoff, which occurs while the ground is still frozen. In addition, in inland regions evaporation exceeds precipitation during summer months, and therefore summer runoff is limited (Hasholt \& Søgaard, 1978). Finally, the lack of inflow streams limits transport of organic debris into the lakes, as evidenced by the absence of visible terrestrial macrofossils in the lake sediments. This dominance of autochthonous $\mathrm{C}$ in these arctic lakes contrast with boreal systems, which commonly have a high external DOC supply from the catchment (Sobek et al., 2003; Algesten et al., 2004). Ouflow losses of $C$ are probably quite low at many lakes in SW Greenland, because of the low precipitation and runoff. In the closed-basin, oligosaline lakes, $C$ is either buried or lost to the atmosphere as $\mathrm{CO}_{2}$. The retention time of the freshwater lakes, although not known specifically, is likely very long, because the outflows at most lakes do not flow during the summer (N. J. Anderson, field observations), thus outflow loss of $C$ is minimal.

\section{Comparisons with the terrestrial C stocks}

Jensen et al. (2006) estimated soil standing stocks (to a depth of $60 \mathrm{~cm}$ ) on Disko Island (some $300 \mathrm{~km}$ further north than Søndre Strømfjord) to be $2.6 \pm 0.7 \mathrm{~kg} \mathrm{C} \mathrm{m}^{-2}$ for well-drained Cassiope-dominated heath and $8.4 \pm 2.4 \mathrm{~kg} \mathrm{C} \mathrm{m}^{-2}$ for wetter Salix-Betula dominated heaths, with a mean total OC burden of $6.7 \mathrm{~kg} \mathrm{C} \mathrm{m}^{-2}$. These values are similar to those reported for sites from eastern Greenland and Svalbard (Elberling et al., 2004; Elberling, 2007) $\left(6.4-10.5 \mathrm{~kg} \mathrm{C} \mathrm{m}^{-2}\right)$ but less than those quoted for 'tundra' (21.6 kg C m${ }^{-2}$; Schlesinger, 1997). Given the moisture stress on south facing slopes in SW Greenland, where vegetation is very sparse and limited to Dryas-cushion plant communities with a low $\mathrm{C}$ content $\left(1.7 \mathrm{~kg} \mathrm{~m}^{-2}\right.$; cf. Bliss \& Matveyeva, 1992), it is reasonable to conclude that only the wetter parts of the landscape (interfluves, lake outflow seepage areas) will have a total $\mathrm{C}$ content in excess of $10 \mathrm{~kg} \mathrm{C} \mathrm{m}^{-2}$ (e.g. Salix snow beds: $21 \mathrm{~kg} \mathrm{C} \mathrm{m}^{-2}$; Elberling et al., 2004).

These values for total arctic soil C content (Oechel \& Billings, 1992; Hobbie et al., 2000) are all considerably less than that the standing stock reported here for lakes and underscore their importance for long-term $\mathrm{C}$ burial (Stallard, 1998; Cole et al., 2007). Using an average total tundra soil content of $6.7 \mathrm{~kg} \mathrm{~m}^{-2}$ (Jensen et al., 2006), the estimated total terrestrial soil C burden in the Søndre Strømfjord region is $8.23 \times 10^{13} \mathrm{~g} \mathrm{C}$ (Table 3). The implication is that the C content of the Søndre Strømfjord lakes is comparable to that buried on land but in only $\sim 14 \%$ of the land area. Small lakes, i.e. $<100$ ha, numerically the most important in the Søndre Strømfjord region, contain $\sim 5 \times 10^{13} \mathrm{~g} \mathrm{C}$ in about $5 \%$ of the land area. These results confirm the importance of lakes in regional $\mathrm{C}$ balances highlighted by Kortelainen et al. (2004) where lakes were second only to peatlands in their ability to store C.

\section{Conclusion}

Future global change processes may impact the large C-pools in arctic soils (Oechel \& Billings, 1992) with associated implications for both regional and global climate (Chapin et al., 2000). Lakes have tended to be ignored in regional C-models (Chapin et al., 2000) despite clear evidence that they can be net sources of $\mathrm{CO}_{2}$ to the atmosphere (Kling et al., 1991, 1992; Sobek et al., 2005; Cole et al., 2007) Moreover, although plant biomass may increase with higher air temperatures and nutrient levels associated with microbial activity, there is growing evidence for soil $\mathrm{C}$ loss due to increased mineralization of soil $\mathrm{C}$ by bacterial activity at the same time as the landscape 'greens' (Mack et al., 2004). As the soil C pool declines with accelerated global warming and greater mineralization of soil C, the importance of the lake sediment component, which is essentially permanent may increase. When the long-term burial of $\mathrm{C}$ by lakes is coupled with their ability to respire terrestrially derived DOC in the water column, their importance for C-cy- 
cling in the arctic is unambiguous. There is a clear need for regional landscape scale C-balances and the results of this study suggest lakes need to be incorporated more fully into these estimates (Kortelainen et al., 2004; Cole et al., 2007; Prairie, 2008).

\section{Acknowledgments}

Thanks to Mark Szegner for help with the analysis of the Landsat image. Financial support was provided by the Danish Natural Science Research Council and NSF (ATM-0081226).

\section{References}

Algesten G, Sobek S, Bergstrom AK, Agren A, Tranvik LJ, Jansson M (2004) Role of lakes for organic carbon cycling in the boreal zone. Global Change Biology, 10, 141-147.

Anderson NJ, Brodersen KP, Ryves DB, McGowan S, Johansson LS, Jeppesen E, Leng MJ (2008) Climate versus in-lake processes as controls on the development of community structure in a low-arctic lake (South-West Greenland). Ecosystems, 11, 307-324.

Anderson NJ, Harriman R, Ryves DB, Patrick ST (2001) Dominant factors controlling variability in the ionic composition of West Greenland Lakes. Arctic Antarctic and Alpine Research, 33, 418-425.

Anderson NJ, Leng MJ (2004) Increased aridity during the early Holocene in West Greenland inferred from stable isotopes in laminated-lake sediments. Quaternary Science Reviews, 23, 841-849.

Anderson NJ, Stedmon CA (2007) The effect of evapoconcentration on dissolved organic carbon concentration and quality in lakes of SW Greenland. Freshwater Biology, 52, 280-289.

Bliss LC, Matveyeva NV (1992) Circumpolar arctic vegetation. In: Arctic Ecosystems in a Changing Climate: An Ecophysiological Perspective (eds. Chapin FS III, Jefferies RL, Reynolds JF, Shaver GR, Svoboda S), pp. 59-89. Academic Press, San Diego.

Böcher TW (1949) Climate, soil, and lakes in continental West Greenland in relation to plant life. Meddelelser om Grønland, 147, 1-61.

Chapin FS, McGuire AD, Randerson J et al. (2000) Arctic and boreal ecosystems of western North America as components of the climate system. Global Change Biology, 6, 211-223.

Cole JJ, Prairie YT, Caraco NF et al. (2007) Plumbing the global carbon cycle: integrating inland waters into the terrestrial carbon budget. Ecosystems, 10, 171-184.

Cotner JB, Biddanda BA, Makino W, Stets E (2004) Organic carbon biogeochemistry of Lake Superior. Aquatic Ecosystem Health and Management, 7, 451-464.

Dahl-Jensen D, Mosegaard K, Gundestrup N, Clow GD, Johnsen SJ, Hansen AW, Balling N (1998) Past temperatures directly from the Greenland ice sheet. Science, 282, 268-271.
Dean WE (1974) Determination of carbonate and organic-matter in calcareous sediments and sedimentary-rocks by loss on ignition - comparison with other methods. Journal of Sedimentary Petrology, 44, 242-248.

Dean WE, Gorham E (1998) Magnitude and significance of carbon burial in lakes, reservoirs, and peatlands. Geology, 26, 535-538.

Downing JA, Cole JJ, Middelburg JJ et al. (2008) Sediment organic carbon burial in agriculturally eutrophic impoundments over the last century. Global Biogeochemical Cycles, 22, GB1018, doi: 10.1029/2006GB002854

Elberling B (2007) Annual soil $\mathrm{CO}_{2}$ effluxes in the high Arctic: the role of snow thickness and vegetation type. Soil Biology and Biochemistry, 39, 646-654.

Elberling B, Jakobsen BH, Berg P, Sondergaard J, Sigsgaard C (2004) Influence of vegetation, temperature, and water content on soil carbon distribution and mineralization in four high Arctic soils. Arctic Antarctic and Alpine Research, 36, 528-538.

Hasholt B, Søgaard H (1978) Et forsøg på en klimatisk-hydrologisk regionsinddeling af Holsteinborgs Kommune (Sisimiut). Geografisk Tidsskrift, 77, 72-92.

Hobbie SE, Schimel JP, Trumbore SE, Randerson JR (2000) Controls over carbon storage and turnover in high-latitude soils. Global Change Biology, 6, 196-210.

Jensen LA, Schmidt LB, Hollesen J, Elberling B (2006) Accumulation of soil organic carbon linked to Holocene sea level changes in west Greenland. Arctic Antarctic and Alpine Research, 38, 378-383.

Kalff J (2002) Limnology. Prentice Hall, Upper Saddle River.

Kane DL, Hinzman LD, Woo M-K, Everett KR (1992) Arctic hydrology and climate change. In: Arctic Ecosystems in a Changing Climate: An Ecophysiological Perspective (eds. Chapin FS III, Jefferies RL, Reynolds JF, Shaver GR, Svoboda S), pp. 35-57. Academic Press, San Diego.

Kaufman DS, Ager TA, Anderson NJ et al. (2004) Holocene thermal maximum in the western Arctic $\left(0-180^{\circ} \mathrm{W}\right)$. Quaternary Science Reviews, 23, 529-560.

Kettle H, Thompson R, Anderson NJ, Livingstone DM (2004) Empirical modeling of summer lake surface temperatures in southwest Greenland. Limnology and Oceanography, $49,271-282$.

Kling GW, Kipphut GW, Miller MC (1991) Arctic lakes and streams as gas conduits to the atmosphere: implications for tundra carbon budgets. Science, 251, 298-301.

Kling GW, Kipphut GW, Miller MC (1992) The flux of $\mathrm{CO}_{2}$ and $\mathrm{CH}_{4}$ from lakes and rivers in Arctic Alaska. Hydrobiologia, 240, 23-36.

Kortelainen P, Pajunen H, Rantakari M, Saarnisto M (2004) A large carbon pool and small sink in boreal Holocene lake sediments. Global Change Biology, 10, 1648-1653.

Lindeberg C, Bindler R, Renberg I, Emteryd O, Karlsson E, Anderson NJ (2006) Natural fluctuations of mercury and lead in Greenland Lake sediments. Environmental Science and Technology, 40, 90-95.

Lizotte MP (2008) Phytoplankton and primary production. In: Polar Lakes and Rivers: Limnology of Arctic and Antarctic Aquatic Ecosystems (eds. Vincent WF, LaybournParry J), pp. 157-178. Oxford University Press, Oxford. 
Mack MC, Schuur EAG, Bret-Harte MS, Shaver GR, Chapin FS (2004) Ecosystem carbon storage in arctic tundra reduced by long-term nutrient fertilization. Nature, 431, 440-443.

McGowan S, Juhler RK, Anderson NJ (2008) Autotrophic response to lake age, conductivity and temperature in two West Greenland lakes. Journal of Paleolimnology, 39, 301-317.

McGowan S, Ryves DB, Anderson NJ (2003) Holocene records of effective precipitation in West Greenland. Holocene, 13, 239-249.

Meyers PA (1994) Preservation of elemental and isotopic source identification of sedimentary organic-matter. Chemical Geology, 114, 289-302.

Oechel WC, Billings WD (1992) Effects of global change on the carbon balance of Arctic plants and ecosystems. In: Arctic Ecosystems in a Changing Climate: An Ecophysiological Perspective (eds. Chapin FS III, Jefferies RL, Reynolds JF, Shaver GR, Svoboda S), pp. 139-168. Academic Press, San Diego.

Oechel WC, Cook AC, Hastings SJ, Vourlitis GL (1997) Effects of $\mathrm{CO}_{2}$ and climate change on arctic ecosystems. In: Ecology of Arctic Environments (eds. Woodin SJ, Marquiss M), pp. 255-273. Blackwell, Oxford.

Prairie YT (2008) Carboncentric limnology: looking back, looking forward. Canadian Journal of Fisheries and Aquatic Sciences, 65, 543-548.
Rippey B, Anderson NJ, Renberg I, Korsman T (2008) The accuracy of methods used to estimate the whole-lake accumulation rate of organic carbon, major cations, phosphorus and heavy metals in sediment. Journal of Paleolimnology, 39, 83-99.

Sand-Jensen K, Riis T, Markager S, Vincent WF (1999) Slow growth and decomposition of mosses in Arctic lakes. Canadian Journal of Fisheries and Aquatic Sciences, 56, 388-393.

Schlesinger WH (1997) Biogeochemistry: An Analysis of Global Change. Academic Press, San Diego.

Sobek S, Algesten G, Bergstrom AK, Jansson M, Tranvik LJ (2003) The catchment and climate regulation of $\mathrm{pCO}(2)$ in boreal lakes. Global Change Biology, 9, 630-641.

Sobek S, Tranvik LJ, Cole JJ (2005) Temperature independence of carbon dioxide supersaturation in global lakes. Global Biogeochemical Cycles, 19, GB2003, doi: 10.1029/2004GB002264

Stallard RF (1998) Terrestrial sedimentation and the carbon cycle: coupling weathering and erosion to carbon burial. Global Biogeochemical Cycles, 12, 231-257.

van Tatentove FGM, van der Meer JJM, Koster RD (1996) Implications for deglaciation chronology from new AMS age determinations in central West Greenland. Quaternary Research, 45, 245-253.

Willemse NW, Tornqvist TE (1999) Holocene century-scale temperature variability from West Greenland lake records. Geology, 27, 580-584. 